\title{
Participación de Medicina Comunitaria en la Feria Expo Jóvenes 2015
}

Reseña: Ángela María Hernández P.*****

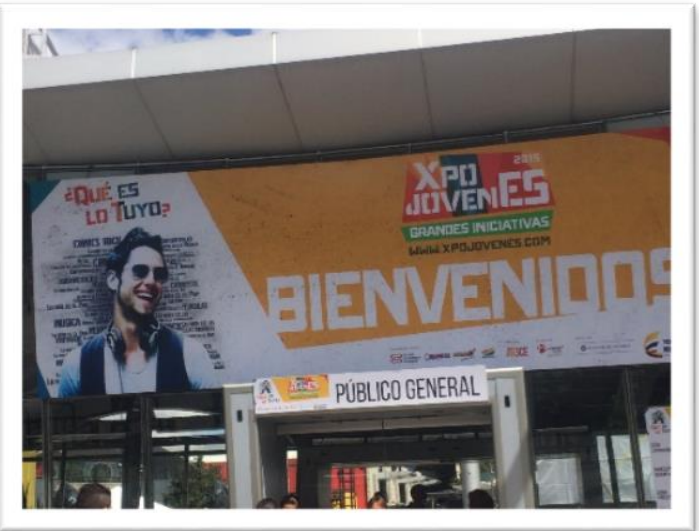

El pasado 26 de septiembre del año en curso en la Feria Expo Jóvenes realizada en Corferias, el Departamento de Medicina Comunitaria participó con el programa PIPSA. Nuestro auditorio, un

grupo de niños entre los 6 a 11 años de edad, sus padres y un maestro, quienes participaron activamente de la charla "Programa integral para la promoción de la salud en adolescentes - PIPSA".
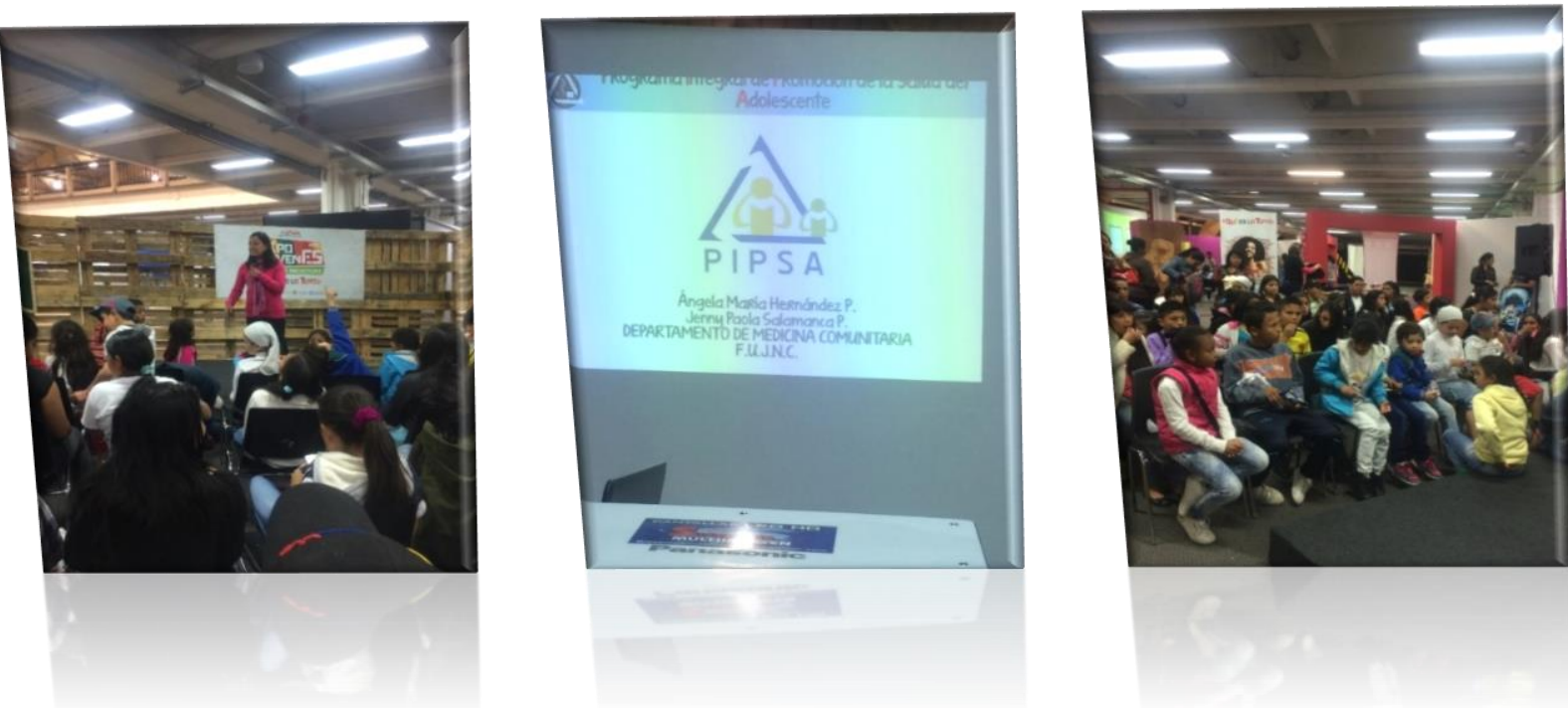

Gracias a la FUJNC, a sus directivas y al Departamento de Mercadeo por permitir este espacio para dar a conocer una de tantas actividades que se desarrollan en la Escuela de Medicina.

**** MD, Magíster Educación. Especialista en Salud Familiar. Profesor Agregado FUJNC. angela.hernandez@juanncorpas.edu.co. 